References will be found, for example, in Mr. H. K. Donisthorpe's recent book on "British Ants" to the species Myrmica rubra and Lasius niger, which are probably those noticed by Miss Armitage. Her observation is of interest in showing how the workers direct the exodus of the winged forms when weather conditions become favourable.--EDITor.

\section{THE ADOPTION OF THE METRIC} SYSTEM.

$\mathrm{T}^{\mathrm{H}}$ $\mathrm{HE}$ controversy with reference to the metric system appears to have passed through two stages and to be approaching the climax of its third, and possibly final, stage. In the first stage the glamour of its uniformly applied denary scale, and of its carefully related standards of length, area, volume, and weight, carried the general public in an apparently wholehearted advocacy which was clearly reflected in the early divisions on the Metric Bill in Parliament. Advocates of the binary scale might attend metric meetings and tear up sheets of paper into two, four, and eight parts; theorists with the duo-denary scale might drag a red-herring across the trail; workers with the most convenient of the English weights and measures might voice their fears of a bad exchange in units of measurement; but the metric advocates carried the day, in most cases with a wonderful accompaniment of popular, if not business, enthusiasm.

The second stage was reached when the practical business men were actually forced to take cognisance of the movement and either accept, or work vigorously against, it. The natural thing happened-how could it be expected that British controllers of industry-industry inductively developed-should be other than short-sighted and insular in their ideas? The nation which deliberately attempted to cut itself off from the Continent in the sixteenth century by adopting a different Latin pronunciation was not likely in the nineteenth to be ready to accept at once any Continental standard, even in weights and measures. Every conceivable objection was raised-and it is perhaps as well that this was so; for we now understand much more clearly the "pros and cons" of the case.

Possibly the greatest difficulty, which has still to be overcome, is the inborn tendency not only of British, but also of all traders to vary their trading conditions. "Tare and tret" accounts have onlv just vanished from our book-keeping37 inches are still allowed to the yard; there are several pounds; apparently a stone may be $8 \mathrm{lb}$., I4 lb., or I6 lb.; a hundred may be a hundred, or a hundred and twelve, or a hundred and twenty (a great hundred) units; while we have also such things as "strikes," “bags," “boxes," etc., of very questionable contents. Such variations tend to promote that "opportunism" which is at daggers drawn with the wider and more humane view of commerce. The tendency to perpetuate this heterogeneity is not only British; it is international, and is undoubtedly one of the weaknesses which mankind as a whole must face and fight if larger opportunities for international service are to be won.

This inherent tendency explains why even among metric nations the metric system has not always conserved its pure form, and why among nonmetric nations the metric system has not been introduced even into recently developed industries. Man has to fight against himself, or rather against certain of his intuitive tendencies, to become the controller of his own environment. Thus, when Mr. W. R. Ingalls, in his paper read before the Institution of Mining and Metallurgy on May 24, confesses to thinking more clearly in the pound than in the kilogram, the present writer is reminded of how for years his personal unit of weight was the $8-1 b$. to $9-1$ b. hare which he carried when accompanying certain of his relatives on their shooting expeditions. The suggestion undoubtedly is that the sooner we definitely teach our young people to work and think in carefully standardised units, instead of allowing them to adopt units accidentally coming within their cognisance, the better for us as a nation and for the world in the broadest sense. Have we yet realised the advantages of deliberate intent, as distinct from casual drift, in this and other similar problems which we must face?

We are now in the third stage, in which the objections to the denary scale and the metric units have practically disappeared. Thus the two problems which to-day are being seriously debated are :

(r) If the metric system is the only possible system that may be universally adopted, will the expense entailed in its adoption by non-metric countries be more than balanced by the advantages gained in the reasonably immediate future?

(2) If it is desirable to adopt wholeheartedly the metric system throughout our industries, how may this best be effected with reference to both our working staffs and the material means by which metric measurements may be made?

With reference to the first proposition, there is no need to discuss the possibility of the universal adoption of the British system rather than the metric system, for two reasons. The first is that there is no British system. Take the textile industries as an example. The Bradford manufacturer speaks a more difficult textile language to the Leeds manufacturer than the Continental manufacturer employing the metric system; and instances might be multiplied. Again, the most standardised of all the British systems-the avoirdupois-scarcely bears signs of its British origin on its face. The second reason is that year by year, month by month, and almost week by week, our industries are being more and more controlled from their laboratories-and all scientific laboratories adopt the metric system. What confusion and mistakes there will ultimately be unless uniformity is here enforced !

Looking at the problem from the broadest basis, Mr. Ingalls' paper is a delightfully unconscious portrayal of the typical British (or American) attitude of mind. We must make our drawings in our own units, and if the French want them they 
must re-draw them. If Russia, China, and South America want British or American productions, they must buy them in our sizes. But surely we have attained a broader outlook than this? If not, the future for our industries is not of the brightest. Will Japan, for example, follow such a lead or take the broader view?

Granted, then, that the metric is now the only possible universal system, will it pay Britain and the United States to adopt it? The answer to this question entails the consideration, in the first place, of what the expenses are likely to be, and, in the second, of what return may reasonably be expected. In the paper already referred to, and particularly in an article on "The Metric System : Its Meaning for the Machine Shop," appearing in the Times Engineering Supplement of May 25, the expenditure that would be entailed in making the proposed change is advanced as the main and most potent reason against the proposal. This argument is exactly that which advocates for the change would expect and wish to answer. The question is now brought down, or rather elevated to a practical issue which those who are for and those who are against must seriously face. Action must be taken one way or the other, and a decision on this particular, and possibly dominant, issue may readily be arrived at. Instead of the writer in question quoting only capital expenditure on gear cutters, drills and reamers, screwing tackle, measuring instruments, machine tools and gears, let him also supply a trading account-a yearly turnover account-based upon a standard plant on which the expenses of the proposed change may also be arrived at. Here is a simple one taken from the textile industries (a worsted drawing plant) :-

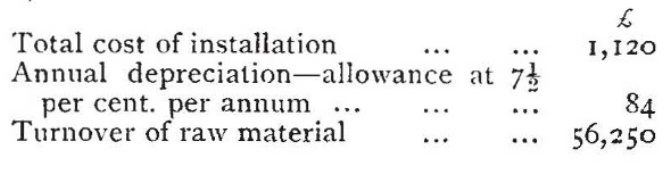

From this it must be evident that two of our greatest industries, cotton and wool, have much more serious questions to face than capital charges; and in these days, when we do not hesitate to spend 9,000,0ool. a day on the war, there must be something more than a mere statement of expenses, however small or however great, if such an objection as that advanced by the writer in the Times Engineering Supplement is to be seriously considered. There must be a careful balancing up, with all the disadvantages and the advantages in full view. The writer can state, without hesitation from personal experience, that at least in certain of our industries not only would there be a prospect of recuperating from the inevitable expenditure within a reasonable limit of time, but also that from the day the metric system was adopted there would be a credit side to the account.

If, then, it be granted that it is desirable wholeheartedly to adopt the metric system, the practical means of carrying this into effect should immediately be thought out and the train laid and fired. Here is straight away a splendid use for No. 2496, VOL. 99] our schools and colleges. The task that will be set them is one which, if their teaching staffs will rise to the occasion, will revitalise mathematical knowledge, introducing inspiration in the place of the too often orthodox deadness and stimulating both the teacher and pupil. The task of supplying the necessary weights and measures might well be left in the hands of those who would first instruct, and then organise into an active force, the more capable of our men returning from the front on the declaration of peace. What an opportunity for organising and carrying into effect a movement that would be a credit even to a nation which has so valiantly helped to withstand, at all too short a notice, the onslaught of the greatest military force the world has ever seen.

The alternative to the compulsory adoption of the metric system throughout our industries at once is its gradual introduction trade by trade; but of the alternatives we prefer the former. Already certain manufacturers are prepared to run their factories on the metric system, and are only deterred from so doing by the necessity of training every fresh hand that enters their establishment from non-metric factories. With this difficulty removed by suitable legislation, the advantage is most markedly on the side of the metric system. At least, this is the firm opinion of those who have worked under both systems in British and Continental workshops and factories.

A. F. B

\section{PROF. W. B. CLARKE.}

7 HE death of William Bullock Clarke on July 27 deprived Maryland of one of its most distinguished men of science. He came of an old New England family, his ancestors having crossed in the "Mayflower." $\mathrm{He}$ was born in Vermont in 1860, and after taking a degree at Amhurst College studied at Munich from r 884-87, where he obtained the degree of $\mathrm{Ph} . \mathrm{D}$. He returned the same year to Baltimore to the post of geological instructor at Johns Hopkins University, and in 1894 became professor and head of the Department of Geology there. $\mathrm{He}$ used his vacations and spare time in working for the Geological Survey of the United States, on the regular staff of which he remained until 1907. Most of his work for the survey was on the Cretaceous and Kainozoic rocks of the coast district, and he helped in the geological survey of the country around Philadelphia and Trenton.

His most important single piece of research is probably his bulletin on the Mesozoic echinoids of the United States. He was, however, led from research by his skill as an organiser. In 1892 he founded the Maryland State Weather Service, of which he remained director until his death. In $x 896$ he established the Maryland Geological Survey and became State geologist. Under his direction the State Survey issued a series of geological reports which are notable both for their breadth of view and their unusually excellent form. As State geologist he was responsible for the Road Service, on which, before its separation 